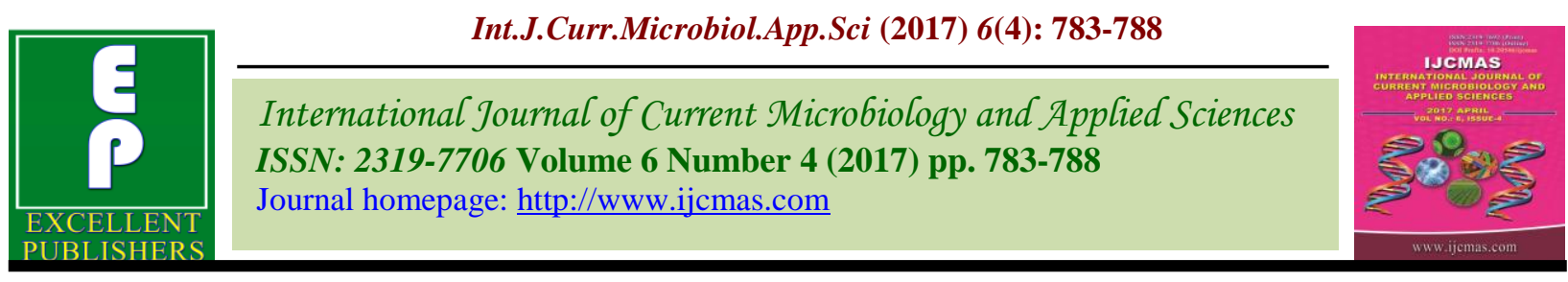

Original Research Article

https://doi.org/10.20546/ijcmas.2017.604.098

\title{
Isolation and Screening of Amylase Producing Fungi
}

\author{
Sujeeta, Kamla Malik*, Shikha Mehta and Khushboo Sihag \\ Department of Microbiology, College of Basic Sciences and Humanities, Chaudhary Charan \\ Singh Haryana Agricultural University, Hisar, Haryana-125004, India \\ *Corresponding author
}

\begin{tabular}{|c|c|}
\hline & A B S T R A C T \\
\hline Keywords & \multirow{4}{*}{$\begin{array}{l}\text { The purpose of this study was to isolate and screened amylase producing fungi } \\
\text { from different sources. A total of twenty amylase producing fungal isolates were } \\
\text { obtained from soil, fruits, vegetables, baked food, and flour on the starch mineral } \\
\text { agar medium. It was observed that ten fungi and ten yeasts isolates produced } \\
\text { amylase, only nine fungal colonies showed positive results for amylase } \\
\text { production. The maximum amylase activity shown by yeast isolates YPO3 } \\
(3.2 \mathrm{~cm}) \text { followed by YBR } 2(3.1 \mathrm{~cm}) \text {. Preliminary morphological observations of } \\
\text { selected fungal isolates colonies were black, green, white, creamy, yellow, } \\
\text { reddish, powdery, flat, round, raised and shiny. The highest enzyme activity was } \\
\text { produced by YPO3 }(13.72 \mathrm{U} / \mathrm{ml}) \text { isolate after } 120 \mathrm{hr} \text { of incubation. }\end{array}$} \\
\hline $\begin{array}{l}\text { Amylase, starch } \\
\text { mineral agar } \\
\text { medium, yeast } \\
\text { isolates, Fungi. }\end{array}$ & \\
\hline Article Info & \\
\hline $\begin{array}{l}\text { Accepted: } \\
\text { 06 March } 2017 \\
\text { Available Online: } \\
10 \text { April } 2017\end{array}$ & \\
\hline
\end{tabular}

\section{Introduction}

In recent years, the uses of microorganisms have become a huge importance to food, textile, baking and detergent industries and sparked a large interest into the exploration of enzyme activity in microorganisms (Sivaramakrishnan et al., 2006). Amylases are among the most important enzymes which hydrolyze starch molecules to give diverse products including dextrin and progressively smaller polymers composed of glucose unit (Gupta et al., 2009). These enzymes are among the most important enzymes for biotechnology with great significance, constitute a class of industrial enzymes having approximately $25 \%$ of the world enzyme market. Amylases can be obtained from several sources, such as plants, animals and microorganisms. Today a large number of microbial amylases are available commercially and they have almost completely replaced chemical hydrolysis of starch in starch processing industry. Major advantage of using microorganisms for the production of amylases is the economical bulk production capacity and the fact that they are easily manipulated to obtain enzymes of desired characteristics (Karnwal and Nigam, 2013). Amylase can be obtained from several fungi, yeast, bacteria and actinomycetes; however, especially fungi, have gained much attention because of the availability and high productivity of fungi, which are also amenable to genetic manipulation. Many fungi had been found to be good sources of amylolytic enzymes. Many studies indicated that amylases of fungal origin are more stable than those of bacterial origin (Sanghvi et al., 2011). Starch is the best substrate for 
production of yeast cells in a large scale due to its low price and easily available raw material in most regions of the world. Because most of yeasts from environments are safe (GRAS) compared to bacteria, interest in amylolytic yeasts has increased in recent years as their potential value for conversion of starchy biomass to single-cell protein and ethanol has been recognized. To date, it has been noticed that the terrestrial yeasts which can produce extracellular amylolytic enzymes include Arxula adeninivorans, Candida japonica, Filobasidium capsuligenum, Lipomyces, Saccharomycopsis, Schwanniomyces (Knox et al., 2004).

Amylases can be classified into two classes, endoamylases ( $\alpha$-amylase) and exoamylases (glucoamylase). $\quad \alpha$-amylase $\quad$ catalyze hydrolysis of $\alpha$-1,4-glucosidic linkages in the interior of starch molecule in a random manner producing branched and linear oligosaccharides (dextrin, maltose, maltotriose, glucose) of different chain length while glucoamylases catalyze hydrolysis of $\alpha$ 1,4- and $\alpha$-1,6-glucosidic linkages in starch molecule (amylase and amylopectin) from its nonreducing end yielding glucose (Khan and Priya, 2011).

Genetically modified microorganisms can be used for the production of various types of enzymes having different characteristics, by genetic make up of our interest of our interest. Microbial technology plays an important role for the production of industrially important enzymes to make up their needs and now a day they are commercially available.

Considering the industrial importance of amylase, in this study, we aimed to isolate and screened amylase producing fungi and yeasts from different sources and to determine the amylase activity.

\section{Materials and Methods}

\section{Isolation of amylase producing fungi}

Samples were collected from different sources viz. soil, fruits, vegetables, baked food, and flour. Serial dilution was made and plated on potato dextrose agar and starch mineral agar medium by spreading $0.1 \mathrm{ml}$ of the diluted sample. Then the plates were kept for incubation at $37^{\circ} \mathrm{C}$ for 3-4 days. The pure cultures were identified by their morphology and colony characteristics and sub-cultured. The isolates were maintained on PDA and YEPDA medium.

\section{Screening of potent amylase producing fungi by starch hydrolysis test}

The selected fungal isolates were screened for amylolytic activity by starch hydrolysis test on starch agar plate. The selected fungal and yeast isolates were streaked on the starch agar plate and incubated at $37^{\circ} \mathrm{C}$ for $2-3$ days. After incubation iodine solution was flooded with dropper for 30 seconds on the starch agar plate. Presence of blue color around the growth indicates negative result and a clear zone of hydrolysis around the growth indicates positive result. The isolates produced clear zones of hydrolysis were considered as amylase producers and were further investigated.

\section{Enzyme production medium}

Production medium contained $(\mathrm{g} / \mathrm{l}) \mathrm{NaNO}_{3}-$ $1.0 \mathrm{~g} ; \mathrm{MgSO}_{4} .7 \mathrm{H}_{2} \mathrm{O}-0.5 \mathrm{~g} ; \mathrm{FeSO}_{4}-0.01 \mathrm{~g}$; soluble starch $20.0 \mathrm{~g} .100 \mathrm{ml}$ of medium was taken in a $250 \mathrm{ml}$ conical flask. The flasks were sterilized in autoclave at $121^{\circ} \mathrm{C}$ for 15 min and after cooling the flask was inoculated with fungal cultures. The inoculated medium was incubated at $30^{\circ} \mathrm{C}$ in shaker incubator for different incubation time. At the end of the fermentation period, the culture medium was 
centrifuged at $5000 \mathrm{rpm}$ for 15 min to obtain the crude extract, which served as enzyme source. The enzyme activity was assayed following the method of using 3, 5dinitrosalicylic acid.

\section{Results and Discussion}

A total of thirty five fungal isolates were obtained from soil, fruits, vegetables, baked food, and flour on PDA and YEPDA medium. These isolates were screened to obtain a black, green, red, yellow, whitish, powdery, and cottony whereas yeast isolates were white, off white, light yellow, greenish, reddish, shiny and gummy colonies (Table 1).
All the selected isolates were screened for production of amylase using starch plate method resulting in clear zone of starch hydrolysis in the Petri dishes after iodine treatment. Out of them, only ten fungal and ten yeast isolates were found to be positive for amylase production, as determined by measuring the width of the clear zone (zone of hydrolysis) formed around the fungal colonies on starch agar medium (Table 2). The yeast isolate YPO3 showed maximum zone of hydrolysis i.e. $3.2 \mathrm{~cm}$ followed by $\mathrm{YBr} 2$ (3.1) and fungal isolates FP2 $(2.6 \mathrm{~cm})$ and FBa3 $(2.5 \mathrm{~cm})$, respectively (Fig. 1). These isolates were selected for determination of enzyme activity.

Table.1 Phenotypic characteristics of isolated amylolytic fungi and yeast

\begin{tabular}{|l|l|}
\hline Isolate & Characteristics \\
\hline FBa3 & Black, powdery \\
\hline FBa4 & Greenish and powdery \\
\hline FBr1 & Whitish red and flat \\
\hline FBr2 & Light green and flat \\
\hline FM1 & Green, scattered and flat \\
\hline FP1 & White and raised \\
\hline FP2 & Green and raised \\
\hline FPO1 & White and cottony \\
\hline FR1 & Greenish yellow and raised \\
\hline FR2 & Dark green and flat \\
\hline YBr1 & White, smooth and shiny \\
\hline YBr2 & Light yellow and rough \\
\hline YM1 & Reddish and branched \\
\hline YP3 & Light yellow, shiny and gummy \\
\hline YP4 & Creamish, shiny and gummy \\
\hline YPO1 & Light yellow, gummy and shiny \\
\hline YPO2 & Yellow and gummy \\
\hline
\end{tabular}


Table.2 Zone diameter shown by isolated fungi and yeast on starch agar medium

\begin{tabular}{|l|l|}
\hline Isolate & Zone diameter $(\mathbf{c m})$ \\
\hline FBa3 & 2.5 \\
\hline FBa4 & 1.3 \\
\hline FBr1 & 2.3 \\
\hline FBr2 & 2.4 \\
\hline FM1 & 1.3 \\
\hline FP1 & 1.2 \\
\hline FP2 & 2.6 \\
\hline FPO1 & 1.3 \\
\hline FR1 & 2.2 \\
\hline FR2 & 1.2 \\
\hline YBr1 & 3.0 \\
\hline YBr2 & 3.1 \\
\hline YM1 & 2.0 \\
\hline YP3 & 2.0 \\
\hline YPO1 & 2.9 \\
\hline YPO2 & 1.5 \\
\hline YPO3 & 3.2 \\
\hline YPmp1 & 3.0 \\
\hline YW5 & 1.7 \\
\hline YS1 & 2.7 \\
\hline &
\end{tabular}

Fig.1 (A) Zone of hydrolysis shown by YPO3 and (B) FP2

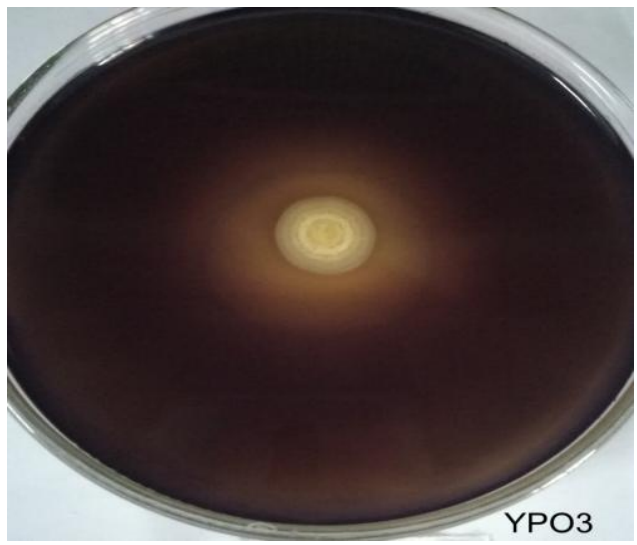

A

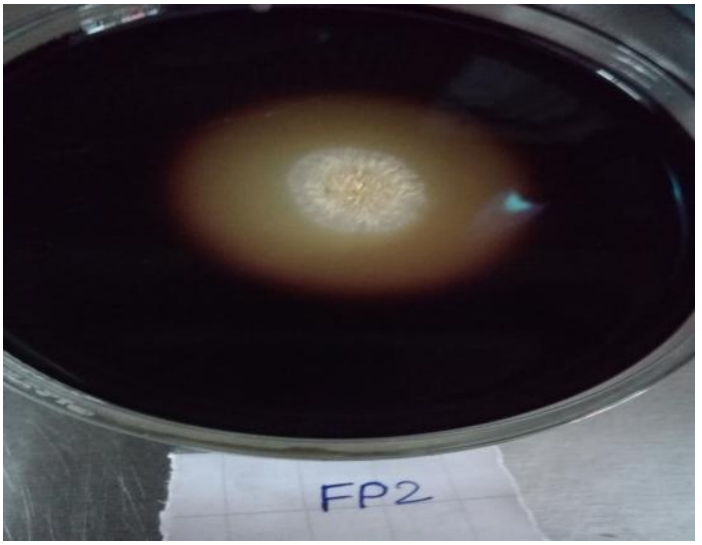

B 
Fig.2 Amlyase activity of selected yeast isolates at different period incubation

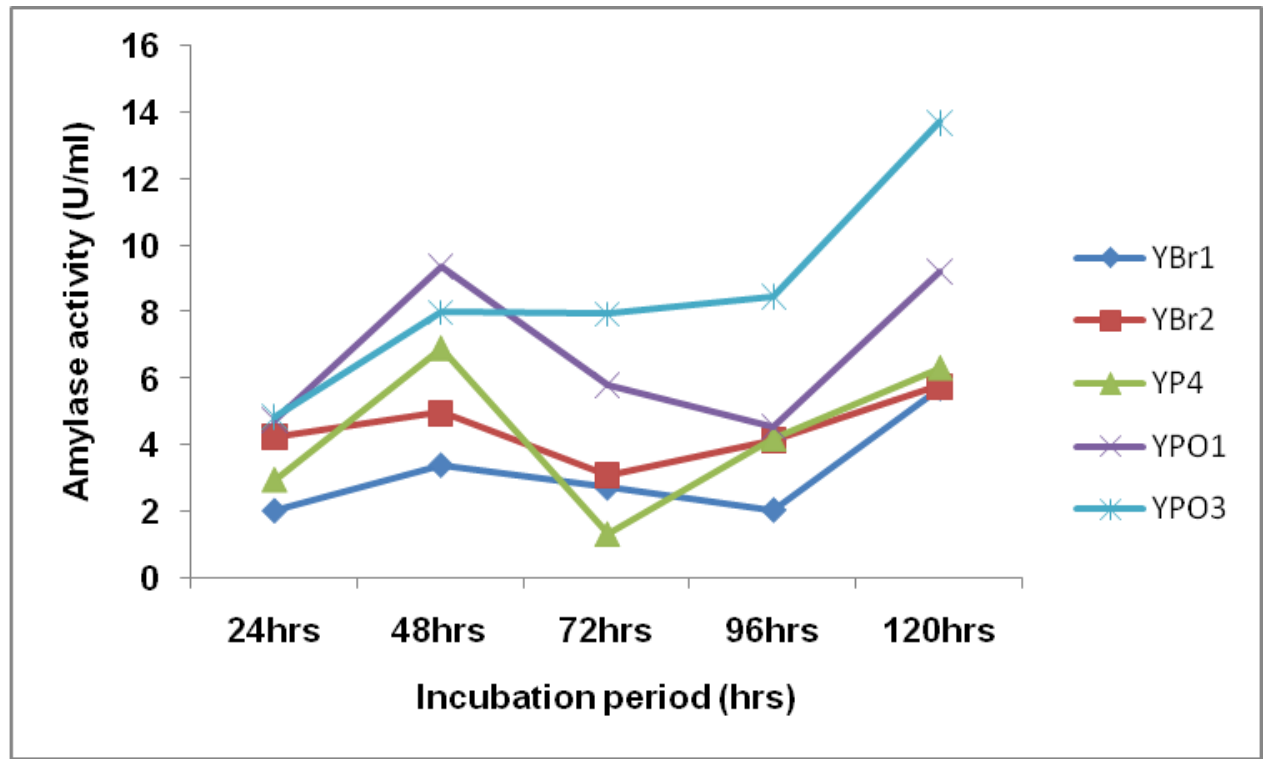

Fig.3 Amlyase activity of selected fungi isolates at different period incubation

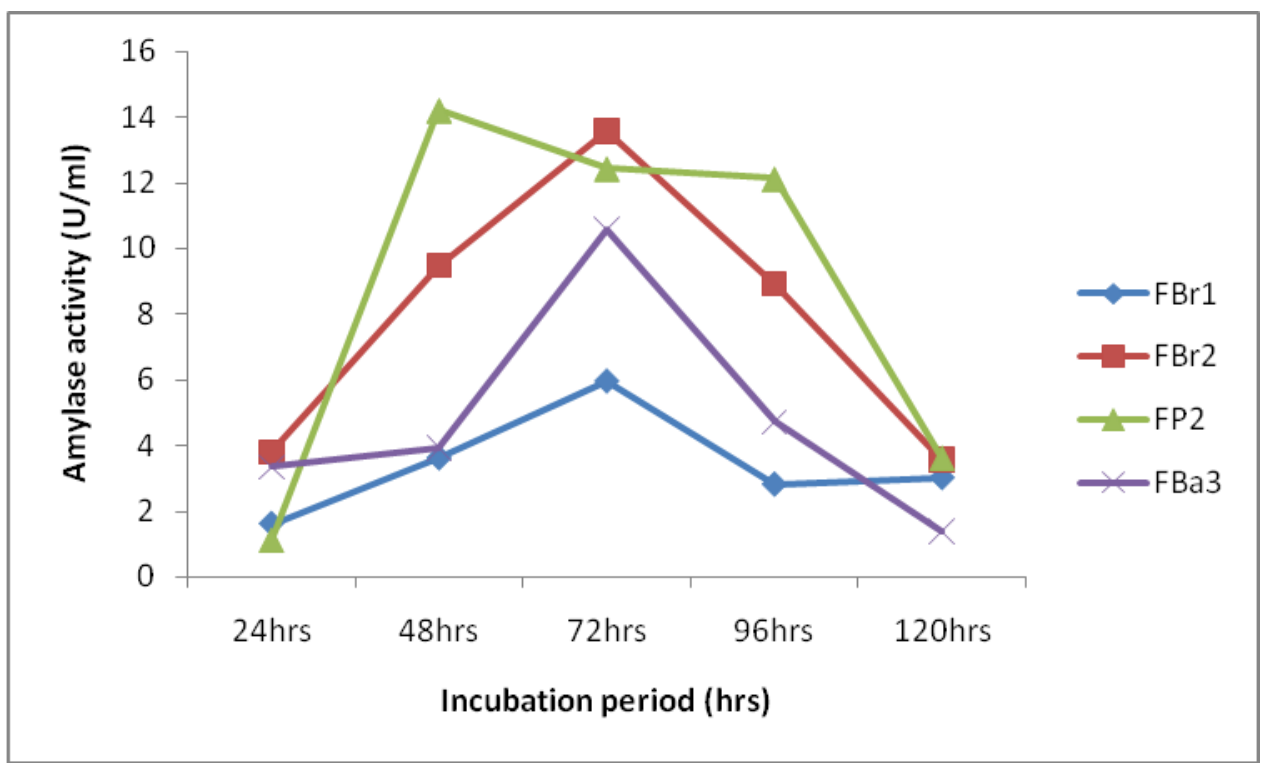

Only four fungal and five yeast isolates were selected for amylase activity. The amylase activity of yeast isolates increase from 2.08 to $9.36 \mathrm{U} / \mathrm{ml}$ as the incubation time increase from 24 to 48 hours at $30{ }^{\circ} \mathrm{C}$ (Fig. 2). The maximum amylase activity was found in YPO3 i.e. $13.72 \mathrm{U} / \mathrm{ml}$ after $120 \mathrm{hrs}$ of incubation. The Fungal isolates FP2 was produced highest amylase activity $13.57 \mathrm{U} / \mathrm{ml}$ in $72 \mathrm{hrs}$ of incubation (Fig. 3). After $72 \mathrm{~h}$ there was gradual decrease in enzyme production. Kathiresan et al., (2006) reported that maximum activity was detected in $96 \mathrm{~h}$ (136 U/ ml) by Penicillium fellutanum under sub merged fermentation and as against a short duration of $24 \mathrm{~h}$ in the case of bacteria. 
The maximum amylase production $(185 \mathrm{U} / \mathrm{ml})$ was found with Aspergillus fumigatus for 6 days of incubation at $30^{\circ} \mathrm{C}$ (Sharma and Shukla, 2008).

In conclusion twenty fungal and yeast isolated were identified for amylase production. Isolates YPO3 and FP2 were showed highest amylolytic activity. The selected isolates can be characterized further for various useful industrial purposes.

\section{References}

Gupta, R., Giras, P., Mohapatra, H., Gaswami, Y.K., Chauhan, B. 2009. Microbial $\alpha-\quad$ amylase: a biotechnological perspective. Process Biochem., 38(11): 1599-1616.

Karnwal, A. and Nigam, V. 2013. Production of amylase by isolated microorganisms and its application. Int. J. Pharm Bio. Sci., 3(4): 354-360.

Kathiresan, K., and Manivannan, S. 2006. $\alpha$ amylase production by Penicillium fellutanum isolated from mangrove rhizosphere soil. African J. Biotechnol., 5(10): 829-832.
Khan, J.A. and Priya, R. 2011. A study on partial purification and characterization of extracellular amylases from Bacillus subtilis. Adv. Appl. Sci. Res., 2(3): 509519.

Knox, A.M., Preez, J.C., Kilian, S.G. 2004. Starch fermentation characteristics of Saccharomyces cerevisiae strains transformed with amylase genes from Lipomyces kononenkoae and Saccharomy copsis fibuligera. Enzyme Microb. Technol., 34(5): 453-460.

Sanghvi, G.V., Koyani, R.D. and Rajput, K.S. 2011. Isolation, optimization, and partial purification of amylase from Chrysosporium asperatum by submerged fermentation, J. Microbiol. Biotechnol., 21: 470-476.

Sharma, D. and Shukla, A.K. 2008. Starch hydrolysis and amylase activity of Aspergillus and Chaetomium. Asian J. Biochem., 3: 284-289.

Sivaramakrishnan, S., D. Gangadharan, K.M. Nampoothiri, C.R. Soccol and A. Pandey. 2006. Alpha amylases from microbial sources. An overview on recent developments. Food Technol. Biotechnol., 44: 173-184.

\section{How to cite this article:}

Sujeeta, Kamla Malik, Shikha Mehta and Khushboo Sihag. 2017. Isolation and Screening of Amylase Producing Fungi. Int.J.Curr.Microbiol.App.Sci. 6(4): 783-788. doi: https://doi.org/10.20546/ijcmas.2017.604.098 